Article

\title{
Microbial analysis of tap water collected from selected upazillas of Jamalpur, Tangail, Kishoreganj and Netrokona districts of Bangladesh
}

\author{
Hosneara Champa and S. M. Lutful Kabir* \\ Department of Microbiology and Hygiene, Bangladesh Agricultural University, Mymensingh-2202, Bangladesh \\ *Corresponding author: Professor Dr. S. M. Lutful Kabir, Department of Microbiology and Hygiene, \\ Bangladesh Agricultural University, Mymensingh-2202, Bangladesh. Phone: +8801754987218; E-mail: \\ 1kabir79@gmail.com, 1kabir79@bau.edu.bd
}

Received: 07 June 2018/Accepted: 26 June 2018/ Published: 30 June 2018

\begin{abstract}
The present study was undertaken to analyze the microbial quality of tap water samples obtained from different upazilla markets of Jamalpur, Tangail, Kishoreganj and Netrokona districts. For achieving the above mentioned objectives, 20 tap water samples were collected and the methods of heterotrophic plate count (HPC) and total coliform count (TCC) were applied. Moreover, isolated E. coli from tap water samples were characterized by using biochemical test, molecular method and antimicrobial susceptibility tests. HPC was highest in market tap water collected from Sarishabari of Jamalpur district and TCC was highest in market tap water collected from Durgapur of Netrokona district. The geometric mean of HPC of Jamalpur, Tangail, Kishoreganj and Netrokona districts water were 4.2x107, 2.7x107, 2.4x107 and 4.4x107 CFU/ml respectively. Out of 13 isolates of E. coli, 13 isolates were amplified by using 16S rRNA gene based PCR. The antimicrobial susceptibility pattern showed that the isolates were highly resistant to amoxicillin. Most of the $E$. coli isolates were susceptible to tetracycline, azithromycin, streptomycin, norfloxacin and ciprofloxacin. Furthermore, a few $E$. coli isolates were intermediate resistant to erythromycin and gentamycin. Moreover, out of 13 E. coli isolates $2(15.4 \%)$ isolates were detected as multidrug resistant. This study indicated the presence of multidrug resistant E. coli isolates in tap water in Jamalpur, Tangail, Kishoreganj and Netrokona districts that warrant particular attention.
\end{abstract}

Keywords: bacteriological safety assessment; tap water; E. coli; antimicrobial resistance; PCR

\section{Introduction}

People can survive days, weeks or months without food, but only about four days without water. Water, although an absolute necessity for life can be a carrier of many diseases. Water can be hard or soft, natural or modified, bottled or tap etc. Water quality is a term used to express the suitability of water to sustain various uses or processes.

Diseases caused by contaminated water consumption and poor hygiene practices are the leading causes of death among children worldwide. Lack of safe drinking water, absence of basic sanitation and hygienic practices are associated with high morbidity and mortality from excreta related diseases (Hassan et al., 2018). Water may be contaminated with pathogens at the source but contamination may also occur during distribution, transportation or handling in households or other working places (Wang et al., 2000). If raw water is used without treatment, it presents a sanitary risk. Inadequate protection of water collection and storage containers and unhygienic conditions contribute to contamination at home.

According to the World Health Report (2000), every year more than 3.4 million people die as a result of water related diseases indicating these as the leading cause of disease and death around the world. In the diseaseprone, humid, tropical region of Bangladesh, outbreaks of diarrheal diseases, often on an epidemic scale, are not unusual and the possible role of water-borne pathogens in these outbreaks has been emphasized. Among water- 
borne diseases of bacterial origin typhoid fever, bacillary dysentery and diarrhea are common in Bangladesh. Despite the availability and promotion of the use of safe water sources, water-related diseases remain an important cause of mortality and morbidity in Bangladesh and it is suggested that intake of contaminated water acts an important mode of pathogen transmission (Karn et al., 2001).

Drinking water is getting polluted with various organic and inorganic matters. The organic matters which are responsible for the contamination of water are fecal wastes of poultry and livestock farms, pesticides, herbicides, and many industrial wastes, minerals and biological agents such as bacteria, virus, fungus, algae etc. Enterobacteriaceae in the water of river Manzanaresat Cumana (Venezuela) and a high degree of enteric species of organisms was present in water (Mieres and Bastardo, 1975). This contaminated water is used for human being, poultry and livestock consumption without treatment and causes various problems and diseases. The role of water as a carrier of disease producing agents was not recognized before the middle of nineteenth century and prior to the establishment of bacteriology as a science. Drinking of this contaminated water causes various enteric diseases of human, poultry and livestock. It is therefore essential to ensure the supply of safe drinking water for poultry and livestock where one fifth of populations of this country are lacking in safe drinking water.

The World Health Organization has estimated that up to $80 \%$ of all sickness and disease in the world is caused by inadequate sanitation, polluted water or unavailability of water. It was estimated that nearly 1.5 billion people lack safe drinking water and that at least 5 million deaths per year can be attributed to water-borne disease. Health effects associated with water supplies in developing countries are evaluated to be based on four bacterial indicators of tropical drinking-water quality (faecal coliforms, Escherichia coli, Enterococci and faecal Streptococci) and their relationship to the prevalence of diarrhoea disease in Cebu, Philippines (Moe et al., 1991). The contaminated water or inadequate supply of safe drinking water causes various gastrointestinal diseases like diarrhoea, dysentery and water borne diseases like cholera, typhoid. It is now evident that most of the enteric diseases of human and animals are transmitted through contaminated food and water (Johnson et al., 2003). So to get rid from suspended biological agents and to ensure the supply of pure drinking water, water must need prior treatment or purified before consumption.

Although the concept of safe water is under consideration in Bangladesh, unfortunately science-based little information is available. Therefore, the present study was conducted to analyze microbial quality of tap water, molecular detection of isolated E. coli and its antimicrobial susceptibility patterns collected from selected upazilla markets of Jamalpur, Tangail, Kishoreganj and Netrokona districts of Bangladesh.

\section{Materials and Methods}

\subsection{Collection and transportation of samples}

Tap water samples from Jamalpur, Tangail, Kishoreganj and Netrokona districts were subjected to quantitative assessment. A total of 20 tap water samples were collected in sterile glass bottles from different upazilas of addressed districts of Bangladesh and transported to the laboratory in ice box containing ice freezer packs. From each sampling point, $250 \mathrm{ml}$ samples were taken for analyses. The bacteriological tests were undertaken within 6 hours after collection to avoid the growth or death of microorganisms in the sample. With regard to the bacteriological analysis, water samples were collected, labeled and transported to the Microbiology laboratory of Bangladesh Agricultural University.

\subsection{Heterotrophic plate count (HPC)}

For the determination of heterotrophic plate count, $100 \mu \mathrm{l}$ of serial tenfold dilution of tap water samples were transferred and spread on plate count agar media using micro pipette for each dilution. The diluted samples were spread as quickly as possible on the surface of plate count agar with a sterile glass spreader. One sterile glass spreader was used for each plate. The plates were then taken in an incubator at $37^{\circ} \mathrm{C}$ for 24 hours. After incubation at $37^{\circ} \mathrm{C}$ for 24 hours plates exhibiting 30-300 colonies were counted. The average number of colonies in a particular dilution was multiplied by the dilution factor to obtain the heterotrophic plate count (HPC). The heterotrophic plate count was calculated according to ISO (1995). The result of total bacterial count was expressed as the number of organism or colony forming units per milliliter (C.F.U/ml) of water samples.

\subsection{Total coliform count}

The most probable number (MPN) test for water examination for the presence of coliforms was performed according to the procedures described by Harley and Prescott (2002). An estimate of the number of coliforms (Most Probable Number) can also be done in the presumptive test. In this procedure, 15 lactose broth tubes were inoculated with the water samples. Five tubes received $10 \mathrm{ml}$ of water, 5 tubes received $1 \mathrm{ml}$ of water, and 5 tubes received $0.1 \mathrm{ml}$ of water. A count of the number of tubes showing gas production was then made, and 
the figure was compared to a table developed by American Public Health Association. The number was the most probable number (MPN) of coliforms per $100 \mathrm{ml}$ of the water sample.

\subsection{Detection of fecal coliforms}

The positive presumptive cultures were transferred to lactose broth, which is specific for fecal coliform bacteria. Any presumptive tube which showed gas production after $24(+/ 2)$ hours incubation at $44.5^{\circ} \mathrm{C}\left(+/ 0.2^{\circ} \mathrm{C}\right)$ confirmed the presence of fecal coliform bacteria in that tube and was recorded as a positive confirmed tube.

\subsection{Isolation and identification of $E$. coli}

The bacteriological examination followed detail study of colony characteristics including the morphological and biochemical properties. In order to find out different types of microorganisms in samples well isolated individual of bacterial colonies were fished out in pure culture from the EMB and MacConkey agar subsequently identified according to the Bergan's manual of determinative bacteriology (1984). Gram's staining was performed to determine the size, shape and arrangement of bacteria. Gram's staining reaction was performed according to the methods described by Merchant and Packer (1976). The organism if E. coli revealed gram-negative, pink color, large rod shape appearance, arranged in single or paired. The isolated organisms with supporting growth characteristics on various media were subjected to different biochemical tests; sugar fermentation test for acid or acid and gas, indole production test, Motility tests, methyl-red and Voges-Proskauer (VP) test. In all cases standard methods as described by Cowan (1985) were followed for conducting these tests.

\subsection{Molecular identification by polymerase chain reaction (PCR)}

Bacterial DNA template was prepared by using boiling method (Englen and Kelley, 2000). All the samples were examined by two pairs of primers (Table 1) to detect $16 \mathrm{~S}$ rRNA gene of E. coli. In case of E. coli., the PCR reactions were carried out using a thermocycler (ASTEC, Japan) with the following programme: initial denaturation with 1 cycle of $5 \mathrm{~min}$ at $95^{\circ} \mathrm{C}, 30$ cycles each consisting of denaturation with $45 \mathrm{sec}$ at $94^{\circ} \mathrm{C}$, annealing with $45 \mathrm{sec}$ at $55^{\circ} \mathrm{C}$, extension with $1 \mathrm{~min}$ at $72{ }^{\circ} \mathrm{C}$ and a final extension step of $5 \mathrm{~min}$ at $72{ }^{\circ} \mathrm{C}$. PCR products were separated on $2 \%$ agarose (Invitrogen, USA) gel, stained with ethidium bromide and photographed using a gel documentation system (BioRad).

\subsection{Antibiotic sensitivity test}

All $E$. coli isolates were tested against eight commonly used antibiotics by the method of disk diffusion as described by Bauer et al. (1966). For this purpose, eight different antibiotic discs were obtained from commercial sources (Himedia, India). The selected antibiotics used were ciprofloxacin (5 $\mu \mathrm{g} / \mathrm{disc})$, azithromycin (30 $\mu \mathrm{g} / \mathrm{disc})$, amoxicillin $(30 \mu \mathrm{g} / \mathrm{disc})$, gentamicin $(10 \mu \mathrm{g} / \mathrm{disc})$, norfloxacin $(10 \mu \mathrm{g} / \mathrm{disc})$, erythromycin $(30$ $\mu \mathrm{g} /$ disc), streptomycin $(10 \mu \mathrm{g} /$ disc $)$, and tetracycline $(30 \mu \mathrm{g} / \mathrm{disc})$. The interpretation on susceptibility was done according to the guidelines of Clinical and Laboratory Standard Institute (CLSI, 2007).

\subsection{Statistical analysis}

The data on heterotrophic plate count (HPC) and Total coliform count (TCC) obtained from the bacteriological examination of tap water collected from different selected upazila of Bangladesh were analyzed in completely randomized design (CRD) using computer package subjected to Analysis of Variance using SPSS Software (Version 16, 2007) . The differences between means were evaluated by Duncan's Multiple Range Test (Gomez and Gomez, 1984).

Table 1. Primers used in PCR for E. coli.

\begin{tabular}{lllll}
\hline Primers & Sequence (5'-3') & Target & \multirow{2}{*}{ Amplicon size (bp) } & Reference \\
\hline ECO-1 & GACCTCGGTTTAGTTCACAGA & E. coli & \multirow{2}{*}{585} & Schippa \\
ECO-2 & CACACGCTGACGCTGACCA & 16S rRNA gene & & et al., 2010 \\
\hline
\end{tabular}

\section{Results}

\subsection{Bacteriological assessment}

\subsubsection{Heterotrophic plate count (H.P.C)}

Heterotrophic plate count (HPC) of tap water of Jamalpur district (Table 2) was $4.2 \times 10^{7}$ CFU/ml. In Jamalpur district, highest heterotrophic plate count (HPC) count was found in water of Sarishabari and the value was $7.3 \times 10^{8} \mathrm{CFU} / \mathrm{ml}$ and the lowest count was in $2.9 \times 10^{6} \mathrm{CFU} / \mathrm{ml}$ found in Dewanganj. 
In case of Tangail district, highest HPC count was found in tap water of TW-9 (Dhanbari) and the count was $4.9 \times 10^{8} \mathrm{CFU} / \mathrm{ml}$ and the lowest count was in tap water of TW-7 (Madhupur) and the count was $2 \times 10^{7} \mathrm{CFU} / \mathrm{ml}$ (Table 2). Average heterotrophic plate count (HPC) count in Tangail district was $2.7 \times 10^{7} \mathrm{CFU} / \mathrm{ml}$.

Heterotrophic plate count of tap water of Kishoreganj district is presented in Table 2. In case of tap water of Kishoreganj district, highest count was found in TW-15 (Bajitpur) and that was 3.6x10 $\mathrm{CFU} / \mathrm{ml}$ and lowest count was found in TW-14 (Pakundia) and that was $1.2 \times 10^{8} \mathrm{CFU} / \mathrm{ml}$. Average heterotrophic plate count (HPC) count in Kishoreganj districts was 2.4x $10^{7} \mathrm{CFU} / \mathrm{ml}$.

In case of tap water of Netrokona district, highest count was found in TW-19 (Atpara) and that was $3.3 \times 10^{8}$ $\mathrm{CFU} / \mathrm{ml}$ and lowest count was found in TW-20 (Barhatta) and that was $2.1 \times 10^{8} \mathrm{CFU} / \mathrm{ml}$. Average heterotrophic plate count (HPC) count in Netrokona district was $4.4 \times 10^{7} \mathrm{CFU} / \mathrm{ml}$.

\subsubsection{Total coliform count (TCC)}

The summary of total coliform count (TCC) of tap water of Jamalpur district is presented in Table 2. In case of Jamalpur district, lowest coliforms was found in tap water TW-5 and the concentration was $<2$ coliforms $/ 100 \mathrm{ml}$ water samples. Highest number of coliforms was found in TW-3. The TCC of tap water sample having sample code TW-1, TW-2, TW-3, TW-4 and TW-5 were 6, 4, 13, 9 and <2 coliforms/100 ml water respectively. In case of Tangail district, highest coliforms was found in tap water TW-6 and the concentration was 11 coliforms $/ 100 \mathrm{ml}$ water samples. Lowest number of coliforms was found in TW-10 and the result was $<2$ coliforms $/ 100 \mathrm{ml}$ water. The TCC of tap water samples having sample code TW-6, TW-7, TW-8, TW-9 and TW-10 were 11, 5, 7, 7 and $<2$ coliforms/100 ml water respectively. In case of Kishoreganj district, highest coliforms was found in TW-11 and the concentration was 11 coliforms/100 ml water sample. Lowest number of coliforms was found in TW-14 water samples and result was $<2$ coliforms $/ 100 \mathrm{ml}$ water. The TCC of tap water samples having sample code TW-11, TW-12, TW-13, TW-14 and TW-15 were $11,7, \quad 9,<2$ and 7 coliforms $/ 100 \mathrm{~m} 1$ water respectively.

Highest coliforms were found in Netrokona in TW-17 and the concentration was 17 coliforms $/ 100 \mathrm{ml}$ water samples. Lowest number of coliforms was found in TW-18 water samples and result was 2 coliforms /100 ml water. The TCC of tap water samples having sample code TW-16, TW-17, TW-18, TW-19 and TW-20 were 14, 17, 2, 7 and 9 coliforms/100 m1water respectively.

Table 2. The summary of HPC and TCC of tap water of Mymensingh, Gazipur and Sherpur district.

\begin{tabular}{|c|c|c|c|c|c|}
\hline $\begin{array}{l}\text { Source of } \\
\text { sample }\end{array}$ & $\begin{array}{l}\text { Sample } \\
\text { code }\end{array}$ & $\begin{array}{l}\text { HPC } \\
(\mathrm{CFU} / \mathrm{ml})\end{array}$ & $\begin{array}{l}\text { Geometric mean of } \\
\text { HPC (CFU/ml) }\end{array}$ & $\begin{array}{l}\text { T.C.C by MPN Method } \\
\text { (coliforms } / 100 \mathrm{ml} \text { ) }\end{array}$ & $\begin{array}{l}\text { Fecal } \\
\text { Coliforms }\end{array}$ \\
\hline \multirow{5}{*}{ 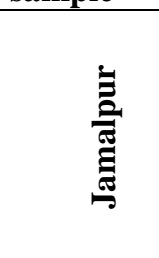 } & TW1 & TNTC & \multirow{5}{*}{$4.2 \times 10^{7}$} & 6 & $+\mathrm{ve}$ \\
\hline & TW2 & 7.3xI08 & & 4 & -ve \\
\hline & TW3 & $2.2 \times 108$ & & 13 & -ve \\
\hline & TW4 & $4.5 \times 108$ & & 9 & -ve \\
\hline & TW5 & $2.9 \times 106$ & & $<2$ & -ve \\
\hline \multirow{5}{*}{ 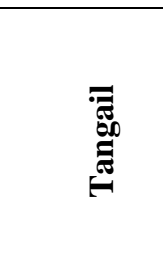 } & TW6 & $1.1 \times 10^{8}$ & \multirow{5}{*}{$2.7 \times 10^{7}$} & 11 & -ve \\
\hline & TW7 & $2 \times 10^{7}$ & & 5 & -ve \\
\hline & TW8 & $4 \times 10^{7}$ & & 7 & -ve \\
\hline & TW9 & $4.9 \times 10^{8}$ & & 7 & -ve \\
\hline & TW10 & $1.3 \times 10^{8}$ & & $<2$ & -ve \\
\hline \multirow{5}{*}{ 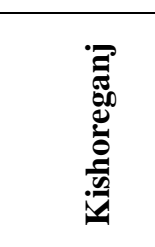 } & TW11 & $\begin{array}{l}1.3 \times 10^{8} \\
\mathrm{CFU} / \mathrm{ml}\end{array}$ & \multirow{5}{*}{$2.4 \times 10^{7}$} & 11 & -ve \\
\hline & TW12 & $3.4 \times 10^{8}$ & & 7 & -ve \\
\hline & TW13 & TNTC & & 9 & $-\mathrm{ve}$ \\
\hline & TW14 & $1.2 \times 10^{6}$ & & $<2$ & $-\mathrm{ve}$ \\
\hline & TW15 & $3.6 \times 10^{8}$ & & 7 & -ve \\
\hline \multirow{5}{*}{ 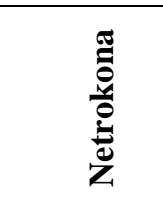 } & TW16 & $8.8 \times 10^{6}$ & \multirow{5}{*}{$4.4 \times 10^{7}$} & 14 & \\
\hline & TW17 & $1.72 \times 10^{8}$ & & 17 & -ve \\
\hline & TW18 & $6 \times 10^{7}$ & & 2 & $-\mathrm{ve}$ \\
\hline & TW19 & $3.3 \times 10^{8}$ & & 7 & -ve \\
\hline & TW20 & $2.1 \times 10^{8}$ & & 9 & -ve \\
\hline
\end{tabular}


3.2. Isolation and identification of $E$. coli from tap water

A total of $13 \mathrm{E}$. coli strains were isolated from 20 tap water samples by using cultural and biochemical techniques.

\subsection{Confirmation of $E$. coli by $16 S$ rRNA gene by PCR}

DNA extracted from $E$. coli isolates was used in the PCR assay. PCR primers targeting 16S rRNA gene of $E$. coli amplified $585 \mathrm{bp}$ fragments of DNA confirmed the identity of E. coli result of PCR for $E$. coli is shown in Figure 1.

\subsection{Antibiogram Study}

\subsubsection{Antimicrobial susceptibility of $E$. coli isolates}

The results of the antimicrobial susceptibility testing by disc diffusion method with 8 chosen antimicrobial agents are presented in Table 3 . Out of $13 \mathrm{E}$. coli isolates, $3(23.1 \%)$ were resistant to erythromycin and $10(77 \%)$ were resistant to amoxycillin, $1(7.7 \%)$ were resistant to azithromycin, 2(15.4\%) were resistant tetracycline. Furthermore, 1(7.7\%) were intermediate resistant to norfloxacin. On the other hand, 10(77\%) were susceptible to ciprofloxacin, 11(84.6\%) were susceptible to streptomycin, azithromycin and $9(69.2 \%)$ were susceptible to gentamicin.

Table 3. Results of Antimicrobial susceptibility of the isolated $E$. coli from tap water.

\begin{tabular}{lllllllll}
\hline Name of isolates & \multicolumn{7}{c}{ No. $(\%)$} \\
\hline E. coli $(\mathbf{n = 2 0})$ & AMX & TE & E & AZM & CIP & S & NOR & GEN \\
\hline Susceptible & $1(7.7)$ & $10(77)$ & $7(53.8)$ & $11(84.6)$ & $10(77)$ & $11(84.6)$ & $10(77)$ & $9(69.2)$ \\
Intermediate & $2(15.4)$ & $1(7.7)$ & $3(23.1)$ & $1(7.7)$ & $2(15.4)$ & 0 & $1(7.7)$ & $2(15.4)$ \\
Resistant & $10(77)$ & $2(15.4)$ & $3(23.1)$ & $1(7.7)$ & $1(7.7)$ & $2(15.4)$ & $2(15.4)$ & $2(15.4)$ \\
\hline
\end{tabular}

[Amoxycilin (AMX), Tetracycline (TE), Erythromycin (E), Azithromycin (AZM), Ciprofloxacin (CIP), Streptomycin (S) Norfloxacin (NOR), Gentamicin (GEN)]

\subsubsection{Antimicrobial resistance pattern of $E$. coli isolates}

The results of antimicrobial resistance pattern of E. coli isolates are summarized in Table 4. Out of 13 E. coli isolates, $12(92.3 \%)$ were resistant to each of 1 antibiotics, in where 6(46.2\%) were resistant to each of 1 antibiotics, $4(30.8 \%)$ were resistant to each of 2 antibiotics, $2(15.4 \%)$ were resistant to each of 3 antibiotics. From this analysis it was evident that $2(15.4 \%)$ E. coli isolates were multidrug resistant when considered resistant to 2 or more drugs.

Table 4. Results of antimicrobial resistance pattern of $E$. coli isolates.

\begin{tabular}{lll}
\hline Isolates & Resistance profiles & No. of Isolates (\%) \\
\hline & No resistance demonstrated & $1(7.7)$ \\
& Resistant to 1 agent (E) & $1(7.7)$ \\
& Resistant to 1 agent (AMX) & $5(38.46)$ \\
& Resistant to 2 agent (AMX - E ) & $1(7.7)$ \\
& Resistant to 2 agent(E-AZM) & $1(7.7)$ \\
& Resistant to 2 agent (AMX-GEN) $(\mathrm{n}=13)$ & $1(7.7)$ \\
& Resistant to 2 agent (AMX--NOR) & $1(7.7)$ \\
& Resistant to 3 agent (AMX-TE-CIP) & $1(7.7)$ \\
& Resistant to 3 agent(AMX-TE-S) & $1(7.7)$ \\
& Resistant isolates & $12(92.3)$ \\
\hline
\end{tabular}

[Amoxycilin (AMX), Tetracycline (TE), Erythromycin (E), Azithromycin (AZM), Ciprofloxacin (CIP), Streptomycin (S) Norfloxacin (NOR), Gentamicin (GEN)] 


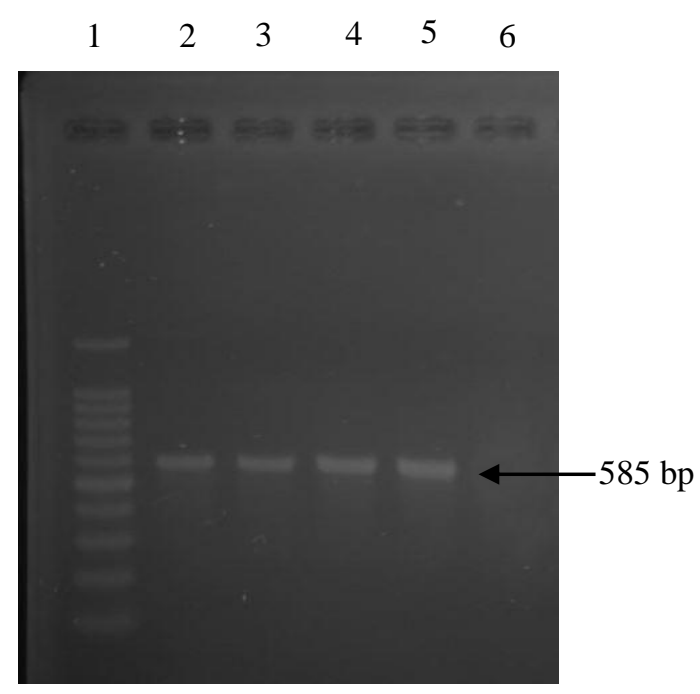

Figure 1. Result of PCR targeting 16S rRNA gene for the identification of $E$. coli. Lane 1: 100 bp DNA size marker, lane 2, 3, 4, 5: genomic DNA of $E$. coli and lane 6: negative control without DNA.

\section{Discussion}

The primary objective of this research work was to analyze the microbial quality of tap water samples collected from selected upazilla markets of Jamalpur, Tangail, Kishoreganj and Netrokona districts. Heterotrophic plate count (HPC) and total coliform count (TCC) are commonly used to assess the general microbiological quality of tap water.

The geometric mean of HPC of Jamalpur, Tangail, Kishoreganj and Netrokona districts water was 4.2x10 ${ }^{7}, 2.7$ $\times 10^{7}, 2.4 \times 10^{7}$ and $4.4 \times 10^{7} \mathrm{CFU} / \mathrm{ml}$. On the other hand, the MPN values of the tap water samples were $6,4,13$, $9,<2,11,5,7,7,<2,11,7,9,<2,7,14,17,2,7,9$ coliforms/100 ml respectively. In this study, it was found that HPC was highest in market tap water collected from Sarishabari of Jamalpur district and TCC was highest in market tap water of collected from Durgapur from Netrokona district and it was about 17 coliforms $/ 100 \mathrm{ml}$.

According to the world health report (2002), drinking water quality specifications world-wide recommend HPC limits from 100 to $500 \mathrm{cfu} / \mathrm{ml}$ in tap water. In this study, HPC was too high in case all types of tap water and high HPC measurements might be due to availability of favourable conditions for the bacterial growth in pipe system. The present study also revealed that tap water from different sources were contaminated with $E$. coli and other unidentified bacteria. In most cases, the pipe system is very old and most of the pipes are poor in condition. There are leakage and breakage through which contaminants from outside the pipe might enter and get mixed with the supplied water. Due to lack of adequate water these pipes are often out of pressure. There is also an illegal practice of drawing water from pipes by suction. As a result, the pressure in the water main becomes less than the atmospheric pressure. Both of these phenomena might cause easier entrance of contaminants into pipelines. Moreover, due to improper layout of water supply lines and sewer lines there might be crossing between them. This might cause fecal contamination. Thus, it is very much possible that even if the water, while entering the pipes, satisfy the specification, it might no longer potable and palatable at the user's end. The findings of the present study correlate with the findings of Islam et al. (2010).

A total of 13 isolates were identified as E. coli on the basis of cultural and biochemical characteristics and $16 \mathrm{~S}$ rRNA gene based PCR from tap water samples used in this study. The fermentation reaction by the isolates of E. coli in five basic sugars (dextrose, sucrose, fructose, maltose, and mannitol) was positive. Moreover, MR reaction and catalase tests were also positive for $E$. coli. The organism was able to ferment lactose, dextrose and mannitol, sucrose and maltose completely. The result of sugar fermentation tests agreed with the findings of Karn et al. (2001). These respective authors reported that although E. coli ferments all 5 basic sugars but it partially fermented sucrose and maltose. Variation of the results might be due to genetic factors and nature of inhabitant of the organisms. Malaney and Weiser (1962) isolated E. coli from pond water. Dragas and Tratnik (1975) stated that $21.5 \%$ of water was contained E. coli. Lin et al. (1974) and Mieres and Bastardo (1975) isolated E. coli from river water. Johnson et al. (2003) detected E. coli and Salmonella in surface water. AbdelMagid (1997) concluded that if the total coliform count becomes too numerous in water it should warrant more attention. Kravitz et al. (1999) found coliforms in all unimproved and semi-improved water sources and they 
considered these types of water as non-potable. They however found that E. coli was absent in majority of the improved water sources. The findings of the present study obviously demonstrated that protection of water sources is very important and the avoidance of contamination can promote hygienic quality of water supplies, where disinfection is not possible. Nogueria et al. (2003) and Shelton et al. (2006) found fecal pollution of water samples. The findings of the present study correlate with the findings of Nogueria et al. (2003) who found highest load of coliform organism in tap water samples. Analogously Opara (2005) found coliform organisms in two rural communities and the quality of rural water supplied was found to be bacteriologically unsatisfactory. Recent studies of Shayo et al. (2007) obtained high coliform count in a rural district and overall, water supplies in the village. Campos et al. (2002) analyzed the microbiological quality of water samples collected from selected houses and could not detect coliforms. On the other hand, Vollaard et al. (2005) reported that one third of the households, were significantly associated with water contaminated with $>100$ fecal coliforms $/ 100 \mathrm{ml}$. They did not however found any association with water source or any environment was encountered. Campos $e t$ al. (2002) analyzed the microbiological quality of water samples collected from selected houses and found that total coliform count was absent.

E. coli is able to acquire resistance easily; therefore it is a good bio-indicator model for surveillance studies of antimicrobial resistance of antibiotic. In antimicrobial susceptibility testing are agreed with Islam et al. (2010), Kabir et al. (2013) and Hassan et al. (2018). A total of 13 E. coli isolates, 2(15.4\%) were multidrug resistant. These findings are in partial agreement with Nazir et al. (2005) and Hassan et al. (2018). Thus, resistant strains might be emerged by genetic recombination against one or more antimicrobial agent(s).

\section{Conclusions}

The unhygienic and poor condition of tap water in studied areas and sanitary point of view and it has evidenced clearly the undesirable level of bacterial contamination such as $E$. coli which may have attained from different sources. Detection of pathogenic E. coli in tap water samples revealed the fact that the water used in households may harm public health phenomena.

\section{Acknowledgements}

This study was performed in partial fulfillment of the requirements of a M.S. thesis for Hosneara Champa from the Department of Microbiology and Hygiene, Bangladesh Agricultural University, Mymensingh, Bangladesh.

\section{Conflict of interest}

None to declare.

\section{References}

Abdel-Magid HM, 1997. Assessment of drinking water quality in the Al-Gassim Region of Saudi Arabia. Environ. Int., 23: 247-251.

Bergan T, 1984. Methods of Microbiology. Vol. 15. Academic Press INC. (LONDON) Ltd. p. 146.

Campos JADB, FA Farache and JB Faria, 2002. Sanitary quality of water distributed to human consumption through the public supply system of Araraquara-Sao Paulo State. Alim. Nutr., 13: 117-129.

Chatterjee SN, A Maji, S Pratihar, M Manna and G Chandra, 2005. Analysis of drinking water quality and bacteriological examination of drain and canal water in Sodepur, Hooghly of West Bengal. Environment and Ecology, 23: 777-780.

Cowan ST, 1985. Cowan and steel's manual for identification of bacteria ( $2^{\text {nd }}$ editon). Cambridge University Press. Cambridge, London.

Dragas AZ and M Tratnik, 1975. On the value of examination of drinking water and swimming pools for the presence of enteropathogenic E. coli. Microbial Abst., 10: 108-178.

Englen MD and LC Kelley, 2000. A rapid DNA isolation procedure for the identification of Campylobacter jejuni by the polymerase chain reaction. Lett. Appl. Microbiol., 31: 421-426.

Hamilton WP, MI Kim and EL Thackston, 2005. Comparison of commercially available Escherichia coli enumeration tests: implications for attaining water quality standards. Water Research-Oxford. 3: 4869-4878.

Hamner S, SC Broadaway, VB Mishra, A Tripathi , RK Mishra, E Pulcini, BH Pyle and TE Ford, 2007. Isolation of potentially pathogenic Escherichia coli0157: H7 from the Ganges river. Appl. Environ. Microbiol., 73: 2369-2372.

Harley JP and LM Prescott, 2002. Laboratory exercises in microbiology. Fifth Edition, The McGraw-Hill Companies, pp. 285-288. 
Hassan MS, SML Kabir, YA Sarker and MT Rahman, 2018. Bacteriological assessment of tap water collected from different markets of Mymensingh, Gazipur and Sherpur districts of Bangladesh with special focus on the molecular detection and antimicrobial resistance of the isolated Escherichia coli. Asian Australas. J. Food Saf. Secur., 2: 21-28.

Islam S, HA Begum and NY Nili, 2010. Bacteriological safety assessment of municipal tap water and quality of bottle water in Dhaka City: health hazard analysis. Bangl. J. Med. Microbiol., 4: 9-13.

Johnson JYM, JE Thomas, TA Graham, I Townshend, J Byrne, LB Selinger and VPJ Gannon, 2003. Prevalence of Escherichia coli 0157:H7 Salmonella spp. in surface waters of southern Alberta and its relation to manure sources. Can. J. Microbiol., 49: 326-335.

Kabir SML, M Ashaduzzaman, M Abu Saim al-Salauddin, H Farhad, D Amit, H Nazmul, H Shihab, MM Abu Shaleh, KN Suma and RM Mufizur, 2015. Safety assessment of tubewell water at Fulbariapourasava in Mymensingh district of Bangladesh. Int. J. Nat. Soc. Sci., 2: 89-94.

Karn SK and H Harada, 2001. Surface water pollution in three urban territories of Nepal, India and Bangladesh. Environ. Manage., 28: 483-96.

Kravitz JD, M Nyaphisi, R Mandel and E Petersen, 1999. Quantitative bacterial examination of domestic water supplies in the Lesotho highlands: water quality, sanitation, and village health. Bull. World Health Organ., 77: 829-36.

Lin S, RL Evans and DB Beuscher, 1974. Bacteriological assessment of spoon river water quality. Appl. Microbiol., 28: 288-297.

Malaney GW and HH Weiser, 1962. Coliform, enterococci, thermodurics, thermophiles and psychrophiles in untreated farm pond waters. Appl. Microbiol., 10: 44-51.

Merchant IA and RA Packer, 1967. Veterinary Bacteriology and Virology, $7^{\text {th }}$ edn., The Iowa University Press, Ames, Iowa, USA, pp. 286-306.

Mieres RL and JW Bastardo, 1975. Enterobacteria in the waters of the river Manzanares at cumana (Venezuela). Microbial Abst., 10: 11822.

Moe CL, MD Sobsey, GP Samsa and V Mesolo, 1991. Bacterial indicators of risk of diarrhoeal disease from drinking water in the Philippines. Bull. World Health Organ., 69: 305-317.

Nazir KH, MB Rahman, KM Nasiruddin, F Akhtar, MF Khan and MS Islam, 2005. Antibiotic sensitivity of Escherichia coli isolated from water and its relation with plasmid profile analysis. Pak. J. Biol. Sci., 8: 16101613.

Nogueria G, CV Nakamura, MCB Tognim, BA Abreu-Filho, and BP Dias-Filho, 2003. Microbiological quality of drinking water of urban and rural communities, Brazil. Revista-de-Saude-Publica, 37: 232-236.

Opara AA, 2005. Water supplies in some rural communities around Calabar, Cross River State, Nigeria: bacteriology of drinking waters. Southeast Asian J. Trop. Med. Public Health, 36: 1025-1027.

Shayo NB, BE Chove, AB Gidamis and OB Ngoma, 2007. The quality of water in small community supplies of Kingolwira village, Morogoro, Tanzania. Tanzan Health Res. Bull., 9: 56-60.

Shelton DR, JS Karns, JA Higgins, VJS Kessel, ML Perdue, KT Belt, RJ Anelli and C Debroy, 2006. Impact of microbial diversity on rapid detection of enterohemorrhagic Escherichia coli in surface water. FEMS Microbiol. Lett., 261: 95-101.

Vollared AM, S Ali, J Smet, H Asten, S Widjaja, LG Visser, C Surjadi and JT van Diessel, 2005. A survey of the supply and bacteriologic quality of drinking water and sanitation in Jakarta, Indonesia. Southeast Asian J. Trop. Med. Public Health, 36: 1552-1561.

Wang L and B Wang, 2000. Pollution of water sources and removal of pollutants by advanced drinking-water treatment in China. Schriftenr Ver Wasser Boden Lufthyg, 105: 413 -419.

WHO, 2000. Guidelines for drinking-water quality, Surveillance and control of community supplies.V.3, 2nd ed. World Health Organizations, Switzerland, Geneva. 